\title{
Purification and characterisation of a xylanase from Thermomyces lanuginosus and its functional expression by Pichia pastoris
}

\author{
Mark Gaffney $^{\mathrm{a}, *}$, Stephen Carberry $^{\mathrm{b}}$, Sean Doyle ${ }^{\mathrm{b}}$, Richard Murphy ${ }^{\mathrm{a}}$ \\ a Altech Bioscience Centre, Sarney, Summerhill Road, Dunboyne, Co. Meath, Ireland \\ ${ }^{\mathrm{b}}$ National Institute for Cellular Biotechnology, Department of Biology, NUI Maynooth, Co. Kildare, Ireland
}

\section{A R T I C L E I N F O}

\section{Article history:}

Received 15 December 2008

Received in revised form 25 May 2009

Accepted 18 July 2009

\section{Keywords:}

Xylanase

Thermomyces lanuginosus

Protein purification

Physicochemical characterisation

Heterologous expression

\begin{abstract}
A B S T R A C T
A xylanase produced by Thermomyces lanuginosus 195 by solid state fermentation (SSF) was purified 9.3-fold from a crude koji extract, with a 7.6\% final yield. The purified xylanase (with an estimated mass of $22 \mathrm{kDa}$ by SDS-PAGE) retained $18 \%$ relative activity when treated for $10 \mathrm{~min}$ at $100{ }^{\circ} \mathrm{C}$ and approximately $90 \%$ relative activity when incubated at $\mathrm{pH}$ values ranging from 6 to 10 . Xylanase activity in the purified preparation was significantly enhanced following treatment with manganese and potassium chlorides $(p<0.05)$ but significantly reduced by calcium, cobalt and iron $(p<0.05)$. The purified enzyme was also shown to be exclusively xylanolytic. The gene encoding xylanase activity from $T$. lanuginosus 195 was functionally expressed by Pichia pastoris. MALDI-ToF mass spectrometry and zymography were employed to confirm functional recombinant expression. Maximum xylanase titres were achieved following $120 \mathrm{~h}$ induction of the recombinant culture, yielding $26.8 \mathrm{U} / \mathrm{mL}$. Achieving functional protein expression facilitates future efforts to optimise the cultivation conditions for heterologous xylanase production.
\end{abstract}

(c) 2009 Elsevier Inc. All rights reserved.

\section{Introduction}

Lignocellulose is the major component of biomass found in nature, derived from agricultural residues, woods and municipal solid wastes [1]. The structure of lignocellulose is comprised of tightly associated cellulose, hemicellulose and lignin polymers [2]. Generally, such biomass is composed of approximately $40 \%$ cellulose, $20-30 \%$ lignin and 20-30\% hemicellulose, the most abundant of which is xylan [3]. Xylanases, acting on polymeric xylan chains by hydrolysing the osidic bond between xylose subunits, randomly generate smaller xyloolgiosaccharides [4]. The enzymatic degradation of xylan has numerous industrial and commercial applications, including use in animal feed supplementation, Kraft bleaching, paper manufacturing, municipal waste treatment and in the treatment of lignocellulosic materials for bioethanol production [5-7].

Thermomyces lanuginosus is a thermophilic fungus commonly found in composting plant material, with an optimum growth temperate of $40-50^{\circ} \mathrm{C}$ [8-10]. Enzyme production by solid state fermentation (SSF) has been shown to be directly influenced by growth media; however, T. lanuginosus is noted for its inability to produce cellulolytic enzymes [11]. Compared to enzymes from mesophilic sources, thermophilic enzymes tend to be more

\footnotetext{
* Corresponding author. Tel.: +3531 8252244; fax: +35318252246. E-mail address: mgaffney@alltech.com (M. Gaffney).
}

thermostable, a trait believed to be achieved through minor alterations in protein structure [5]. The cultivation conditions required for the growth of thermophiles are generally unsuited to standard industrial fermentations [12]. Consequently, the applicability of thermophilic enzymes relies on their ability to be actively expressed by mesophilic hosts [13].

Amongst common GRAS (generally regarded as safe) listed yeast expression hosts, Pichia pastoris has been extensively utilised both industrially and academically [14]. The use of the methylotrophic yeast $P$. pastoris is of particular interest in heterologous expression as it is typically cultivated at $28^{\circ} \mathrm{C}$ and the strongly induced $A O X 1$ promoter, responsible for alcohol oxidase production, accounts for $35 \%$ of the cellular protein [15]. A distinct advantage of eukaryotic expression hosts is their capacity to facilitate the post-translation modification of proteins [16]. Additionally, extracellular protein secretion from Pichia tends to be low, reducing the competition for secretion machinery during heterologous expression [17]. A wide variety of proteins have been expressed by this system with varying degrees of success with respect to product yield [14].

The objectives of the present study initially began with the purification of a xylanase produced by T. lanuginosus 195 under SSF conditions. Both crude and purified xylanase preparations were analysed to determine specific characteristics. Following on from this, an appropriate expression vector was constructed and the gene encoding xylanase activity from T. lanuginosus 195 was functionally expressed by the $P$. pastoris system. 


\section{Materials and methods}

\subsection{Materials}

The $P$. pastoris expression system (encompassing the pPic9K vector and expression host GS115), chemically competent Escherichia coli and the pCR 2.1 intermediate vector were purchased from Invitrogen (CA, U.S.A.). Restriction enzymes and the Rapid DNA Ligation kit were supplied by New England Biolabs (MA, U.S.A.) The RNAqueous ${ }^{\circledR}$ RNA Isolation Kit was obtained from Ambion (Cambridgeshire, U.K.). The T-Primed First-Strand Kit was supplied by Amersham Biosciences (Freiburg, Germany). The Agarose Gel DNA Extraction Kit was obtained from Roche Applied Science (West Sussex, U.K.). All other reagents were of molecular biology grade or higher where appropriate and supplied by Sigma-Aldrich (MO, U.S.A.). All oligonucleotide primers were synthesised by Sigma-Genosys (Haverhill, U.K.).

\subsection{Fungal strains and culture conditions}

T. lanuginosus 195 was preserved in Alltech's own culture bank at the Alltech Bioscience Centre, Dunboyne, Co. Meath, Ireland. Liquid second seed growth medium consisted of (g/L deionised water): corn starch, 60; peptone, 18; glucose, 5; magnesium sulphate, 1.5; potassium phosphate, 1 ; potassium chloride, 0.5 and was sterilised at $105^{\circ} \mathrm{C}$ for $30 \mathrm{~min}$. Liquid medium was inoculated with $1 \times 10^{6}$ spores $\mathrm{mL}^{-1}$ and incubated for 3 days at $40^{\circ} \mathrm{C}, 200 \mathrm{rpm}$. SSF consisted of $10 \mathrm{~g}$ sterilised wheat bran in $250 \mathrm{~mL}$ Erlenmeyer flasks and inoculated with $10 \mathrm{~mL}$ of liquid culture, diluted 1:4 with sterile water. The flasks were mixed thoroughly and incubated at $40{ }^{\circ} \mathrm{C}, 80 \%$ relative humidity $(\mathrm{RH})$ in a humidity chamber (Sheldon Manufacturing Inc., OR, U.S.A.).

$P$. pastoris GS115 is an auxotrophic mutant defective in histidinol dehydrogenase production. Its generation and growth conditions were previously described by Cregg et al. [15].

\subsection{Detection of xylanase activity}

Upon completion of SSF, the fermented media with treated with $90 \mathrm{~mL}$ deionised water for $90 \mathrm{~min}$ under constant agitation at $200 \mathrm{rpm}$. The crude enzyme preparation was filtered through muslin cloth and centrifuged at $10,000 \times g$ for $10 \mathrm{~min}$ at $4{ }^{\circ} \mathrm{C}$. Similarly, Pichia cultures were centrifuged at $3000 \times \mathrm{g}$ for $10 \mathrm{~min}$ at $4{ }^{\circ} \mathrm{C}$, allowing for the supernatant to be separated from the resulting cellular pellet. Enzyme preparations were examined for total xylanase activity using a modified version of the assay described by Bailey and Poutanen [18], using $2 \%(\mathrm{w} / \mathrm{v})$ birchwood xylan as substrate. Sample absorbance was calculated at $\lambda_{540 \mathrm{~nm}}$ the Shimadzu $160-A$ UV-vis Spectrophotometer (Shimadzu, Japan). One unit of xylanase (U) was defined as the amount of enzyme required to liberate $1 \mu \mathrm{mol}$ of xylose per minute under the assay conditions.

Zymography was used to detect xylanase activity following SDS-PAGE. Birchwood xylan was incorporated into the separating gel, to a final concentration of $0.1 \%(\mathrm{w} / \mathrm{v})$, prior to casting. Following electrophoresis, the xylan containing gel was washed with $25 \%(\mathrm{v} / \mathrm{v})$ isopropanol in $0.1 \mathrm{M}$ sodium acetate, $\mathrm{pH} 5$. The gel was further washed with $0.1 \mathrm{M}$ sodium acetate, $\mathrm{pH} 5$ and incubated in $50 \mathrm{mM}$ sodium citrate $\mathrm{pH} 5.3$ at $60^{\circ} \mathrm{C}$ for $1 \mathrm{~h}$. The gel was then stained with $0.1 \%(\mathrm{w} / \mathrm{v})$ Congo Red.

\subsection{Protein determination}

The protein content of cell free extracts was quantified using the Bradford protein assay reagent with bovine serum albumin (BSA) as standard [19]. Samples were measured at $\lambda_{595 \mathrm{~nm}}$ using a Biotek ${ }^{\circledR}$ Synergy HT microtitre plate reader (Biotek Instruments Inc., U.S.A.) and expressed as milligram or microgram of protein per milliliter of protein sample.

\subsection{Purification strategy}

Extracellular proteins, produced by T. lanuginosus 195 during SSF, were extracted from the fermented media with deionised water for $90 \mathrm{~min}$ with intermittent agitation. Proteins contained within this crude preparation were initially separated by anion exchange chromatography, whereby a $1 \mathrm{~mL}$ aliquot was applied to a column packed with DEAE-Sepharose resin and equilibrated with $25 \mathrm{mM}$ Tris- $\mathrm{HCl}$, pH 8. Proteins adsorbed to the Sepharose resin were eluted with a linear gradient of $0-0.5 \mathrm{M}$ $\mathrm{NaCl}$ in $25 \mathrm{mM}$ Tris- $\mathrm{HCl}, \mathrm{pH}$, at a flow rate of $25 \mathrm{~mL} \mathrm{~h}^{-1}$. Xylanase specific fractions, assessed by spectroscopy at $\lambda_{280 \mathrm{~nm}}$ and colorimetric assay, were concentrated by ultrafiltration and further separated following passage through a Sephadex G-50 matrix, equilibrated with $25 \mathrm{mM}$ potassium phosphate, $\mathrm{pH}$ 8. All purification steps were carried out at $4{ }^{\circ} \mathrm{C}$ unless otherwise stated. Purity was assessed by SDS-PAGE as described by Laemmli [20] and stained using either the SilverSNAP Stain Kit II (Pierce Biotechnology, IL, U.S.A.) or RAPIDstain ${ }^{\text {TM }}$ (Calbiochem, SD, U.S.A.).

\subsection{Thermostability of xylanase}

The thermostability of xylanase in crude and purified preparations was investigated by incubating the enzyme sample for $10 \mathrm{~min}$ at temperatures ranging from
22 to $100^{\circ} \mathrm{C}$, after which aliquots were removed and cooled on ice. Residual activity was determined by colorimetric assay.

\section{7. $\mathrm{pH}$-dependent stability of xylanase}

The pH-dependent stability of xylanase in both crude and purified forms was assessed by incubating samples for $30 \mathrm{~min}$ in $0.2 \mathrm{M}$ buffers. The buffers used to facilitate the required $\mathrm{pH}$ range were; glycine- $\mathrm{HCl}(\mathrm{pH} 2)$, citrate buffer $(\mathrm{pH} 3-6)$, sodium phosphate ( $\mathrm{pH} 7$ and 8) and glycine- $\mathrm{NaOH}$ ( $\mathrm{pH} 9$ and 10). Residual enzyme activity was quantified by colorimetric assay.

\subsection{Effect of potential modulators of xylanase activity}

The effect of metal ions and potential modulators of enzyme activity was determined by incubating xylanase preparations in $10 \mathrm{mM}$ treatments for $30 \mathrm{~min}$ [21] Sample aliquots were removed, diluted with standard assay buffer and xylanase activity was determined by colorimetric assay. Residual activity was expressed as the percentage of activity observed following identical treatment of the enzyme sample in deionised water.

\subsection{Substrate specificity}

The specificity of xylanase preparations was evaluated by replacing birchwood xylan in the standard colorimetric assay with a variety of xylan and non-xylan derived polymeric substrates. The reducing sugars released during the assay were quantified by spectroscopy at $\lambda_{540 \mathrm{~nm}}$ and compared to those values obtained for birchwood xylan.

\subsection{Statistical analysis}

Data was analysed using the Minitab statistical software package, version 15.0 (Coventry, U.K.). All statements of significance were calculated by one-way ANOVA and based on a confidence level of $95 \%$.

\subsection{Construction of an appropriate expression plasmid}

Following fermentation on wheat bran, fungal mycelia were ground under liquid nitrogen. Total RNA was extracted from ground mycelia using the RNAqueous ${ }^{\circledR}$ RNA Isolation Kit as described by the manufacturer (Ambion). First-strand cDNA was generated from $5 \mu \mathrm{g}$ of total RNA using the T-Primed First-Strand Kit (Amersham Biosciences). The xynl gene encoding xylanase activity from $T$. lanuginosus 195 was amplified from cDNA using the primers xynltp, incorporating an EcoRI site (5'-G/AATTCCAGACAACCCCCAACTCGGCTGG-3') and xynlbm, incorporating a NotI site (5'-GC/GGCCGCTTAGCCCACGTCAGCAACGGTGATG-3'). The resulting PCR product was visualised by $1 \%(\mathrm{w} / \mathrm{v})$ agarose gel electrophoresis and subsequently purified using the Agarose Gel DNA Extraction Kit as outlined by the manufacturer (Roche).

The purified PCR product was subcloned into the intermediate PCR 2.1 vector and transformed into competent $E$. coli, allowing for appropriate post-amplification modifications to be made to the xynl gene. DNA manipulations were typically carried out according to the procedures described by Sambrook et al. [22]. Following purification from E. coli, the plasmid was digested with EcoRI and NotI to recover the xynl gene. The xynl gene was subsequently subcloned into the pPic9K expression vector (pre-digested with EcoRI and NotI), yielding a plasmid construct designated p9KXl, with an estimated size of $9855 \mathrm{bp}$.

\subsection{Transformation and expression of $P$. pastoris}

The p9KXl plasmid was linearised with Sall and transformed into competent $P$. pastoris GS115 via electroporation. Cells were treated as described by Cregg and Russell [23] prior to transformation, which was carried out using the MicroPulser electroporator according to the manufacturer's specifications (BIORAD, CA, U.S.A.).

Successfully transformed colonies, evident by growth on selective regeneration plates, were individually cultivated in BMGY medium at $28^{\circ} \mathrm{C}, 250 \mathrm{rpm}$. Cells were harvested by centrifugation $\left(3000 \times g\right.$ for 5 min at $\left.4{ }^{\circ} \mathrm{C}\right)$ and resuspended in the mBMMHY medium described by Chen et al. [24], with an $\mathrm{OD}_{600 \mathrm{~nm}}$ equal to 17.24 . The mBMMHY induction medium consisted of $0.5 \%$ methanol, $0.1 \%$ yeast extract, $1 \%$ $\left(\mathrm{NH}_{4}\right)_{2} \mathrm{SO}_{4}, 4 \times 10^{-5} \%$ biotin, $0.004 \%$ histidine, $100 \mathrm{mM}$ potassium phosphate $\mathrm{pH} 6$. During induction, methanol was added every $24 \mathrm{~h}$ to a final concentration of $0.5 \%$ $(\mathrm{v} / \mathrm{v})$.

\subsection{MALDI-ToF mass spectrometry}

Mass spectrometry (MS) was carried out using an Ettan MALDI-ToF (matrixassisted laser desorption ionisation time of flight) mass spectrometer (Amersham Biosciences, Germany). Protein samples for MS analysis were excised from SDSPAGE gels, digested with trypsin and deposited onto mass spectrometry slides following equal volume mixture with $\alpha$-cyano-4-hydroxycinnaminic acid $(2.5 \%$ $(\mathrm{w} / \mathrm{v})$ in $50 \%(\mathrm{v} / \mathrm{v})$ acetonitrile with $0.1 \%(\mathrm{v} / \mathrm{v})$ aqueous trifluoroacetic acid) [25]. Protein identification was carried out by $\mathrm{m} / \mathrm{z}$ data interrogation of the NCBI nr database using the Mascot search engine. 
Table 1

Purification strategy for xylanase from T. lanuginosus 195.

\begin{tabular}{|c|c|c|c|c|c|}
\hline Step & Activity (Ua $)$ & Protein $\left(\mathrm{mg}^{\mathrm{b}}\right)$ & Specific activity $\left(\mathrm{U} / \mathrm{mg}^{\mathrm{c}}\right)$ & Yield (\%) & Purification factor \\
\hline Crude extract & 897 & 1.350 & 664 & 100.0 & 1.0 \\
\hline IEX & 822 & 0.780 & 1054 & 91.6 & 1.6 \\
\hline Ultrafiltration & 173 & 0.048 & 3604 & 19.3 & 5.4 \\
\hline G-50 & 115 & 0.020 & 5750 & 12.8 & 8.7 \\
\hline Ultrafiltration & 68 & 0.011 & 6182 & 7.6 & 9.3 \\
\hline
\end{tabular}

a Total units of xylanase activity expressed as $\mathrm{U}$.

b Total protein content expressed as milligram.

c Total units of xylanase activity per milligram of protein expressed as $\mathrm{U} / \mathrm{mg}$.

\section{Results}

\subsection{Purification of xylanase following SSF}

Purification of a single xylanase from a crude protein extract of $T$. lanuginosus 195 was facilitated by a combination of ultrafiltration, anion exchange (IEX) and gel filtration chromatographies. The purification scheme employed, summarised in Table 1, resulted in a 9.3-fold purification of xylanase, with a specific activity of $6,182 \mathrm{U} / \mathrm{mg}$ of protein and a final yield of $7.6 \%$. Following silver staining, SDS-PAGE analysis indicated that a single xylanase had been purified to homogeneity (Fig. 1), with an approximate molecular mass of $22 \mathrm{kDa}$.

\subsection{Thermostability of xylanase}

As can be appreciated from Fig. 2, crude and purified xylanase preparations from $T$. lanuginosus 195 demonstrated residual activity across the temperature range investigated. The purified

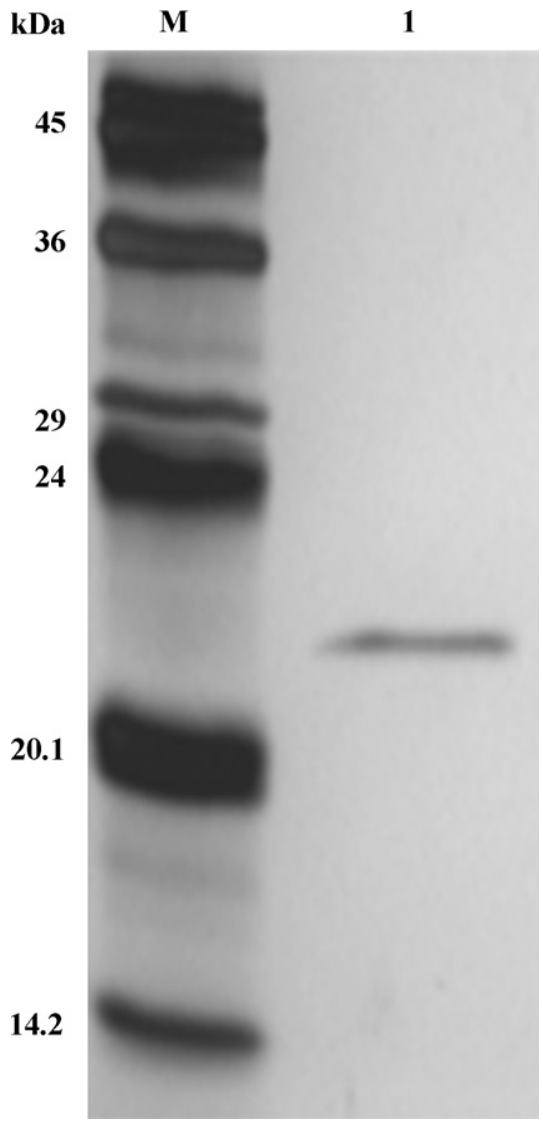

Fig. 1. SDS-PAGE of a purified xylanase from T. lanuginosus 195. M: low range molecular mass markers (kDa), lane 1: purified xylanase from T. lanuginosus 195. xylanase preparation displayed considerable stability when incubated at $70^{\circ} \mathrm{C}$ for $10 \mathrm{~min}$, retaining $87 \%$ relative activity (RA). The enzyme continued to exhibit notable thermal properties, retaining $18 \% \mathrm{RA}$ when incubated at $100^{\circ} \mathrm{C}$. Comparatively, the crude xylanase preparation displayed lower RA between 60 and $80^{\circ} \mathrm{C}$.

\section{3. $p H$-dependent stability of xylanase}

Xylanase present in the crude preparation from $T$. lanuginosus 195 appeared to be relatively stable from $\mathrm{pH} 2$ to 10 , only losing approximately $10 \% \mathrm{RA}$ in more acidic environments (Fig. 3). The purified xylanase preparation was also stable under alkaline conditions, however, relative activity steadily decreased when incubated in acidic buffers, falling from 93\% RA at pH 6 to 22\% RA at pH 2 .

\subsection{Effect of potential modulators on xylanase activity}

As is evident from Table 2, purified xylanase activity was significantly stimulated following individual treatments with $10 \mathrm{mM}$ manganese and potassium chlorides $(p<0.05)$. Conversely, purified activity was significantly reduced in the presence of calcium, cobalt and ferric chlorides $(p<0.05)$. The crude xylanase preparation was not significantly affected by the treatments illustrated in Table 2, with the exception of mercuric chloride, which significantly reduced activity by $39 \%(p<0.05)$.

\subsection{Substrate specificity}

The specificity of both crude and purified xylanase preparations from T. lanuginosus 195 was examined on various substrates,

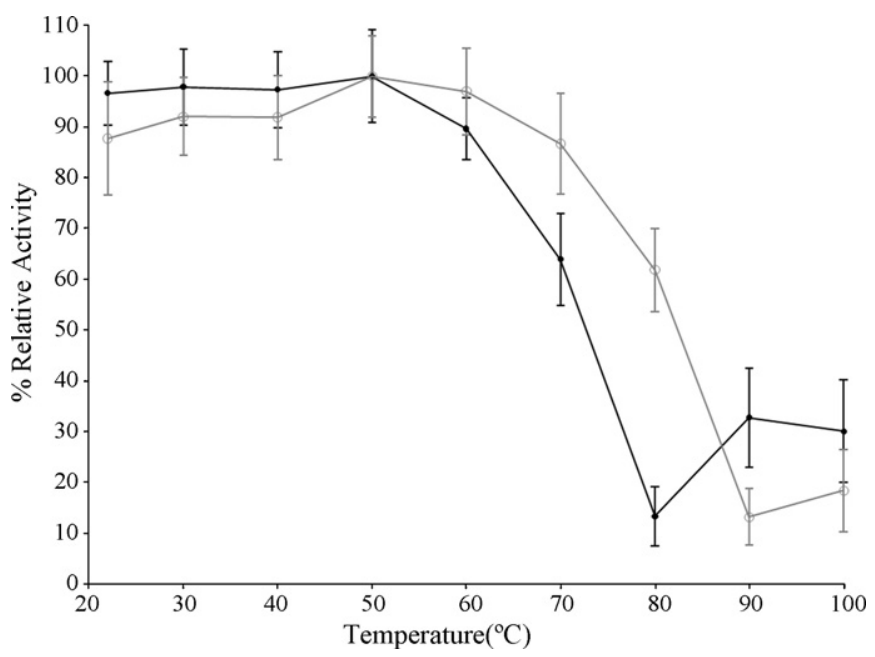

Fig. 2. Thermostability profiles of crude and purified xylanase preparations. Dat plotted is the mean analysis of triplicate flasks for the crude xylanase preparation $(\bullet)$ and the purified xylanase preparation $(\bigcirc)$, with standard deviation represented by error bars. 


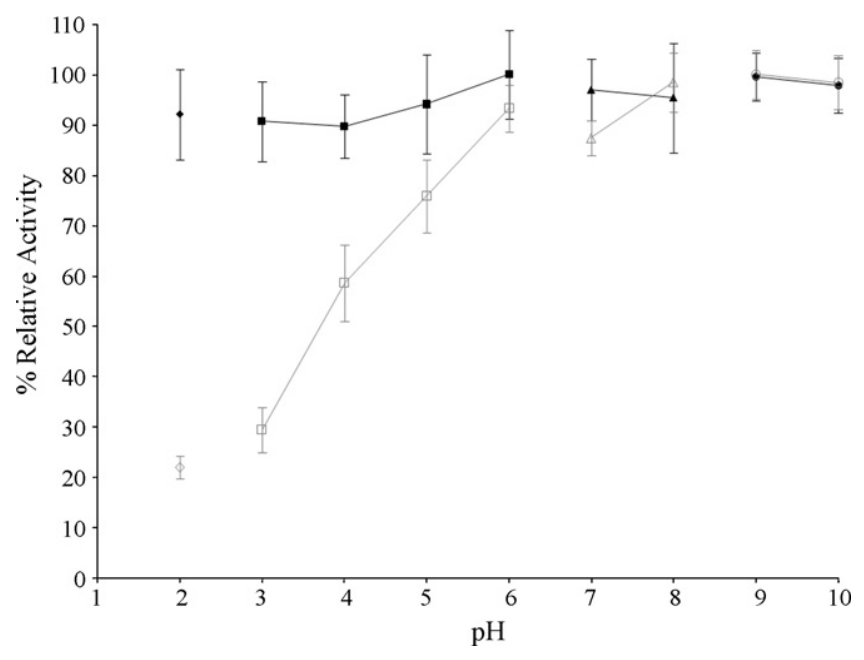

Fig. 3. pH-dependent stability profiles of crude and purified xylanase preparations Data plotted is the mean analysis of triplicate flasks, with standard deviation represented by error bars. The crude xylanase preparation is represented by buffers at:

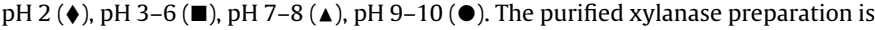
represented by buffers at: pH $2(\diamond)$, pH 3-6 $(\square)$, pH 7-8 $(\triangle)$, pH 9-10 $(\bigcirc)$. the findings of which are presented in Table 3. Results indicated that both the crude and purified enzyme preparations were specifically xylanolytic, displaying a significant increase in activity on oat spelt and beechwood xylans $(p<0.05)$. Xylanase preparations were approximately $43 \%$ more active when oat spelt xylan was used as the substrate. Furthermore, the purified enzyme preparation appeared to display a higher relative activity than its crude counterpart $(21 \%)$ when beechwood xylan was utilised as the assay substrate. The crude xylanase preparation did not display detectable activity when cellulosic substrates were incorporated into the assay, implying that $T$. lanuginosus 195 did not produce cellulolytic enzymes when cultivated on wheat bran.

\subsection{Molecular analysis of $P$. pastoris transformants}

For the purpose of identifying xylanase recombinants, total genomic DNA was extracted from selected transformants and used as a template for PCR amplification using the $5^{\prime} \alpha$ factor primer (Invitrogen) and the xynlbm primer. The fragments (approximately $650 \mathrm{bp}$ ) amplified in lanes $1-4$ of Fig. 4 corresponded in length with the fragment in lane 5 , obtained from the expression vector $\mathrm{p} 9 \mathrm{KXI}$ (positive control). Comparatively, no similar product was amplified when genomic DNA from the negative control (host transformed with pPic9K) was used (lane 6). The generation of a unique DNA fragment from the genomic DNA of a number of transformants

Table 2

Effect of metal ions and potential modulators on xylanase activity.

\begin{tabular}{|c|c|c|c|c|c|c|c|}
\hline \multirow[t]{2}{*}{ Treatment (10 mM) } & \multirow[t]{2}{*}{ Chemical formula } & \multicolumn{3}{|c|}{ Crude preparation } & \multicolumn{3}{|c|}{ Purified preparation } \\
\hline & & $\% A^{a}$ & $\% \mathrm{SD}^{\mathrm{b}}$ & $p$-value ${ }^{\mathrm{c}}$ & $\% \mathrm{RA}^{\mathrm{a}}$ & $\% \mathrm{SD}^{\mathrm{b}}$ & $p$-value ${ }^{c}$ \\
\hline Water (control) & $\mathrm{H}_{2} \mathrm{O}$ & 100.0 & 6.9 & - & 100.0 & 3.2 & - \\
\hline 2-Mercaptoethanol & $\mathrm{C}_{2} \mathrm{H}_{6} \mathrm{OS}$ & 94.4 & 15.8 & 0.585 & 110.0 & 7.3 & 0.116 \\
\hline Aluminium sulphate & $\mathrm{Al}_{2}\left(\mathrm{SO}_{4}\right)_{3}$ & 106.8 & 9.1 & 0.381 & 94.5 & 12.3 & 0.475 \\
\hline Barium chloride & $\mathrm{BaCl}_{2} \cdot \mathrm{H}_{2} \mathrm{O}$ & 100.8 & 16.3 & 0.938 & 96.2 & 9.7 & 0.540 \\
\hline Calcium chloride & $\mathrm{CaCl}_{2}$ & 107.5 & 6.4 & 0.251 & 88.8 & 7.0 & $0.05^{*}$ \\
\hline Chromium chloride & $\mathrm{CrCl}_{3} \cdot 6 \mathrm{H}_{2} \mathrm{O}$ & 100.6 & 14.6 & 0.955 & 85.8 & 13.3 & 0.106 \\
\hline Cobalt chloride & $\mathrm{CoCl}_{2} \cdot 6 \mathrm{H}_{2} \mathrm{O}$ & 100.9 & 15.0 & 0.927 & 80.4 & 4.1 & $0.002^{* *}$ \\
\hline Copper chloride & $\mathrm{CuCl}_{2} \cdot 2 \mathrm{H}_{2} \mathrm{O}$ & 90.0 & 12.4 & 0.258 & 90.3 & 10.7 & 0.174 \\
\hline EDTA & $\mathrm{C}_{10} \mathrm{H}_{12} \mathrm{~N}_{2} \mathrm{O}_{8} \mathrm{Na}_{4}$ & 93.4 & 9.8 & 0.376 & 107.7 & 5.3 & 0.109 \\
\hline Ferric chloride & $\mathrm{FeCl}_{3} \cdot 6 \mathrm{H}_{2} \mathrm{O}$ & 82.0 & 14.5 & 0.087 & 50.0 & 6.2 & $0.000^{* *}$ \\
\hline Magnesium chloride & $\mathrm{MgCl}_{2} \cdot 6 \mathrm{H}_{2} \mathrm{O}$ & 109.6 & 8.4 & 0.222 & 104.9 & 8.7 & 0.426 \\
\hline Manganese chloride & $\mathrm{MnCl}_{2} \cdot 4 \mathrm{H}_{2} \mathrm{O}$ & 100.3 & 5.0 & 0.957 & 112.3 & 2.9 & $0.009^{*}$ \\
\hline Mercurium chloride & $\mathrm{HgCl}_{2}$ & 61.1 & 10.1 & $0.002^{* *}$ & 97.9 & 8.2 & 0.701 \\
\hline Potassium chloride & $\mathrm{KCl}$ & 99.2 & 3.8 & 0.876 & 117.5 & 8.5 & $0.045^{*}$ \\
\hline Sodium chloride & $\mathrm{NaCl}$ & 97.9 & 8.7 & 0.760 & 96.6 & 8.4 & 0.540 \\
\hline Zinc chloride & $\mathrm{ZnCl}_{2}$ & 97.5 & 8.2 & 0.699 & 94.9 & 6.4 & 0.271 \\
\hline
\end{tabular}

a Relative activities (\%RA) are represented by mean triplicate samples.

b Corresponding standard deviation, compared to water (control).

c Probability values determined by one-way ANOVA, with a confidence level of $95 \%$.

${ }^{*} p \leq 0.05$.

** $p \leq 0.005$.

Table 3

Substrate specificity of xylanase activity.

\begin{tabular}{|c|c|c|c|c|c|c|c|}
\hline \multirow[t]{2}{*}{ Substrate $(1 \%, \mathrm{w} / \mathrm{v})$} & \multirow[t]{2}{*}{ Main linkage } & \multicolumn{3}{|c|}{ Crude preparation } & \multicolumn{3}{|c|}{ Purified preparation } \\
\hline & & $\% \mathrm{RA}^{\mathrm{a}}$ & $\% \mathrm{SD}^{\mathrm{b}}$ & $p$-value ${ }^{c}$ & $\% \mathrm{RA}^{\mathrm{a}}$ & $\% \mathrm{SD}^{\mathrm{b}}$ & $p$-value ${ }^{c}$ \\
\hline Birchwood xylan & $\beta-1,4$ & 100.0 & 2.8 & - & 100.0 & 0.8 & - \\
\hline Oat spelt xylan & $\beta-1,4$ & 142.9 & 1.5 & $0.000^{* *}$ & 143.3 & 6.9 & $0.002^{* *}$ \\
\hline Beechwood xylan & $\beta-1,4$ & 111.9 & 3.7 & $0.015^{*}$ & 133.0 & 9.2 & $0.010^{*}$ \\
\hline Carboxymethyl-cellulose & $\beta-1,4$ & ND & - & - & ND & - & - \\
\hline Avicel & $\beta-1,4$ & ND & - & - & ND & - & - \\
\hline Laminarin & $\beta-1,3$ & ND & - & - & ND & - & - \\
\hline
\end{tabular}

ND denotes no enzyme activity detected.

a Relative activities (\%RA) are represented by mean triplicate samples.

b Corresponding standard deviation, compared to birchwood xylan (control).

c Probability values determined by one-way ANOVA, with a confidence level of 95\%.

${ }^{*} p \leq 0.05$.

** $p \leq 0.005$ 


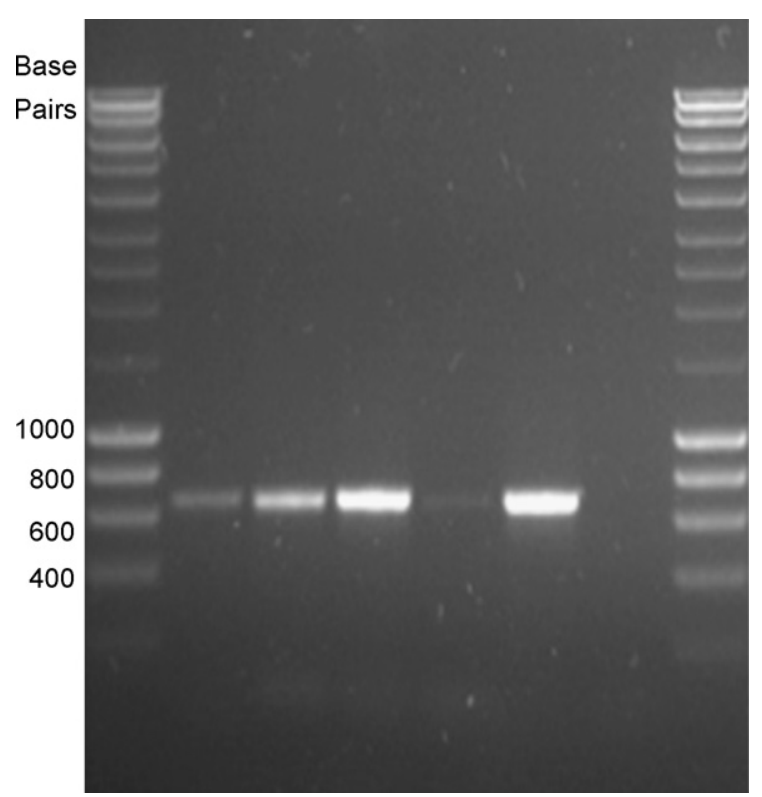

Fig. 4. Molecular analysis of putative Pichia transformants. M: bioline HyperLadder I, lanes 1-4: PCR amplification utilising genomic DNA from putative transformants, lane 5: PCR amplification utilising p9KXl expression vector (positive control), lane 6: PCR utilising host transformed with pPic9K (negative control).

(lanes 1-4), indicated that the heterologous xylanase gene had successfully integrated into the $P$. pastoris genome.

\subsection{Recombinant xylanase production}

Recombinant xylanase expression was assessed using small scale cultures in baffled flasks. During the induction period, aliquots of culture were analysed for xylanase activity and protein content. Maximum xylanase $(26.8 \mathrm{U} / \mathrm{mL})$ and protein production $(236.6 \mu \mathrm{g} / \mathrm{mL})$ were detected following $120 \mathrm{~h}$ induction (Fig. 5). At this stage of the fermentation, cell density, as determined by absorbance at $600 \mathrm{~nm}$, reached its highest value at 20.81 . Prior to methanol induction, the culture had a value of 17.24 . The cell density profile generated during induction mirrored the increase in xylanase activity and protein content. Following $120 \mathrm{~h}$ induction, xylanase activity and protein content within the cul-

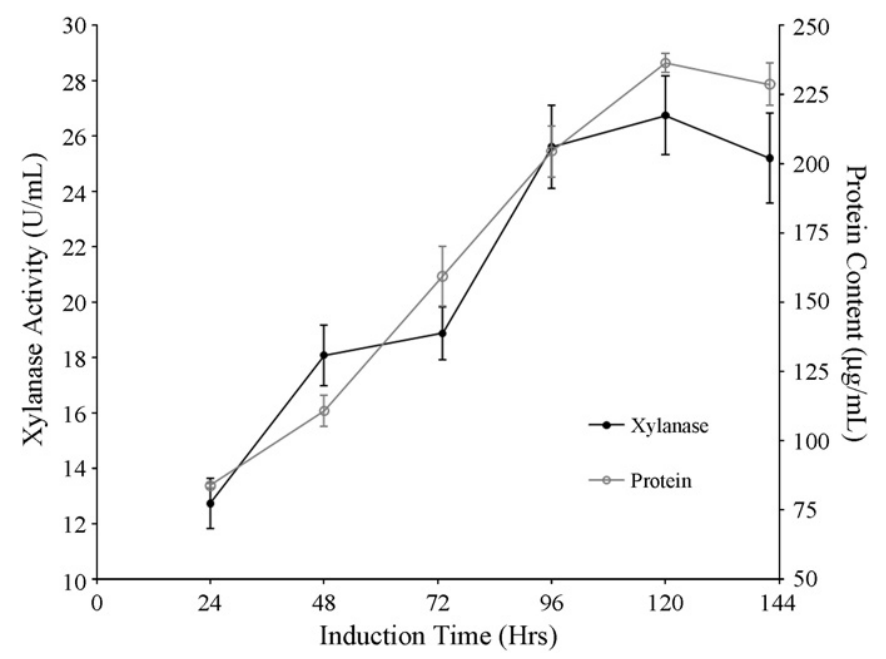

Fig. 5. Recombinant xylanase production. Data plotted is the mean analysis of triplicate flasks for xylanase activity $(\bullet)$ and protein content $(\bigcirc)$, with standard deviation represented by error bars.
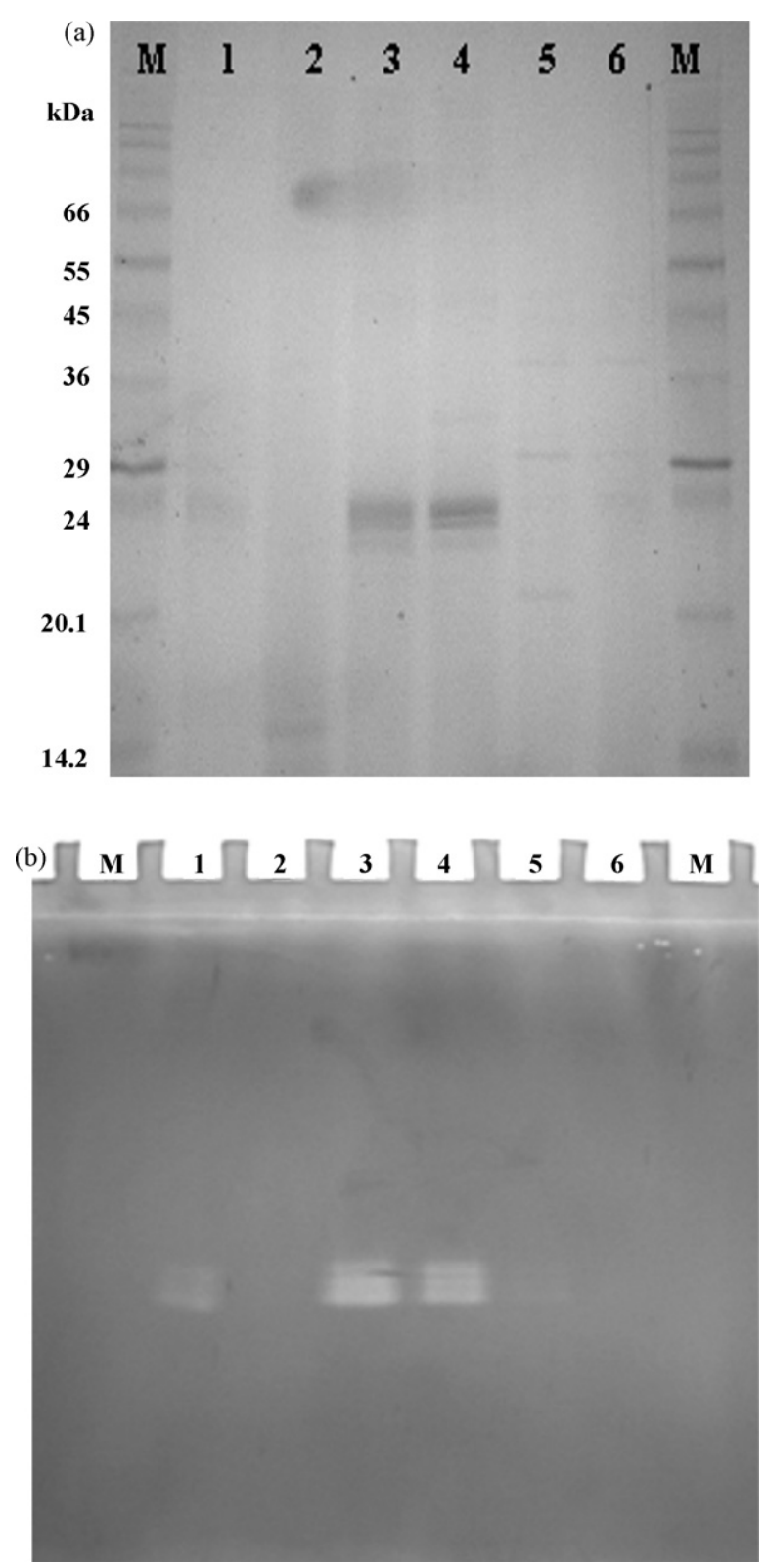

Fig. 6. SDS-PAGE (a) and zymography (b) of induced Pichia transformants. M: wide range molecular mass marker, lanes 1-5: recombinant transformants after $96 \mathrm{~h}$ induction, lane 6: negative control sample after $96 \mathrm{~h}$ induction. SDS-PAGE stained with RAPIDstain ${ }^{\mathrm{TM}}$.

ture declined, as did cell density which dropped to 20.45 at $142 \mathrm{~h}$.

\subsection{Electrophoresis and zymography}

Prior to SDS-PAGE, extracellular proteins were precipitated from the inducing media with $0.02 \%(\mathrm{w} / \mathrm{v})$ sodium deoxycholate and $10 \%(\mathrm{w} / \mathrm{v})$ trichloroacetic acid (TCA) and resuspended in deionised water. A number of transformants generated electrophoretic banding patterns which depicted heterologous protein mass ranging from 22 to $24 \mathrm{kDa}$ (Fig. 6a). Simultaneous zymography confirmed that these bands displayed xylanolytic activity in situ (Fig. 6b).

\subsection{MALDI-ToF mass spectrometry}

Protein bands exhibiting xylanolytic activity were excised, digested with trypsin and analysed by MALDI-ToF MS. Interroga- 
Table 4

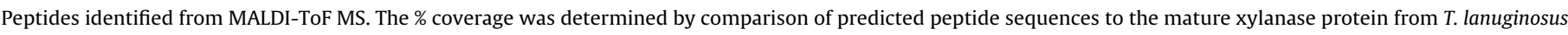
(gi|157834320).

\begin{tabular}{|c|c|c|c|c|c|}
\hline \multirow[t]{2}{*}{ Peptide sequence } & \multicolumn{2}{|l|}{ Mass (Da) } & \multicolumn{2}{|c|}{ Residue endpoints } & \multirow[t]{2}{*}{$\%$ Coverage } \\
\hline & Theortical & Experimental & $\mathrm{N}$-terminus & C-terminus & \\
\hline GWNPGLNAR & 984.501 & 984.495 & 50 & 58 & 4.6 \\
\hline VNAPSIDGTQTFDQYWSVR & 2184.036 & 2183.977 & 123 & 141 & 9.8 \\
\hline \multirow[t]{2}{*}{ AGLNVNGDHYYQIVATEGYFSSGYAR } & 2852.328 & 2851.953 & 162 & 187 & 13.4 \\
\hline & & & Total coverag & & $27.8 \%$ \\
\hline
\end{tabular}

tion against the NCBI nr database identified peptide similarities with a xylanase from T. lanuginosus (gi|157834320) (Table 4). These peptides also shared considerable similarity with a number of xylanases from different genera. In particular, the 2184 Da peptide was identified as a highly conserved sequence in family 11 glycoside hydrolases. The conserved domain was recognised in the Conserved Domain Database (CDD) as pfam00457, sharing similarity with a number of different family 11 xylanases. The individual percentage coverage of each peptide was presented in Table 4, which, when accumulated, accounted for $27.8 \%$ of the mature xylanase from T. lanuginosus (gi|157834320). These results indicated successful expression of the gene encoding xylanase activity from $T$. lanuginosus 195 by $P$. pastoris.

\section{Discussion}

Typical findings for xylanases from strains of $T$. lanuginosus demonstrate that temperature mediated inactivation of enzyme activity produces a slowly decreasing profile and $\mathrm{pH}$-dependent stability is influenced by acidic pHs lower than 5.5 [26]. The characteristics displayed under such conditions may be attributed to disulphide bridging, a trait synonymous with xylanases from $T$. lanuginosus [27]. In the present study, incidences of varying activity between crude and purified xylanase preparations may have been mediated by proteinaceous xylanase inhibitors, common in cereal grains such as wheat bran [28,29]. During extraction of the target xylanase from fermented wheat bran, such inhibitors may have been retained within the crude xylanase preparation prior to characterisation studies. In the absence of these inhibitors, activity in the purified preparation was not influenced in the same manner.

The inhibition of xylanase activity by ferrous ions was previously documented by Deng et al. [30], however, Cesar and Mrsa [31] reported a purified xylanase preparation from $T$. lanuginosus to be stimulated by ferrous ions. These conflicting results suggest that xylanases from different $T$. lanuginosus strains may differ in structure or reaction mechanisms, a postulation also conceded by Cesar and Mrsa [31]. Similarly, mercuric chloride has been reported as a strong inhibitor of xylanase activity [21]. However, in the present study, purified xylanase activity was not significantly influenced by mercuric chloride treatment, suggesting that thiol groups may not have been directly required for catalytic activity.

The heterogeneity of polymeric xylans confers a variety of unique characteristics on individual xylans [32]. Substituents, attached to the xylan backbone, generally act to limit the hydrolytic action of enzymes via steric interference. Oat spelt xylan is recognised as typically having lower concentrations of uronic acids than other xylans [33]. This structural trait may favour the generation of an enzyme-substrate complex, typically associated with xylan hydrolysis. Oat spelt xylan also displays high degrees of substitution, increasing the solubility of the substrate and subsequently increasing the potential for enzymatic degradation [34]. To this end, enhanced activity displayed by the xylanase from T. lanuginosus 195 may also be attributed to the increased solubility of oat spelt xylan. A similar preference to oat spelt xylan was also documented by Damaso et al. [35] for a xylanase produced by T. lanuginosus.
The cultivation conditions required for the growth of thermophilic fungi are generally unsuited to standard industrial fermentations. Consequently, the commercial applicability of thermophilic enzymes relies on their ability to be actively expressed by mesophilic hosts, under more industrially favourable conditions [13]. Various titres of recombinant xylanase from Pichia have been documented in relevant literature. Wakiyama et al. [36] recovered approximately $6 \mathrm{U} / \mathrm{mL}$ following the 5 day induction of a recombinant $P$. pastoris culture. Damaso et al. [37] achieved $360 \mathrm{U} / \mathrm{mL}$ after $96 \mathrm{~h}$ induction, using an optimised medium with $1 \%(\mathrm{v} / \mathrm{v})$ methanol. Ruanglek et al. [38] implemented a fed batch strategy for heterologous xylanase production in $P$. pastoris, achieving $3676 \mathrm{U} / \mathrm{mL}$ over a $165 \mathrm{~h}$ period, which consisted of a $96 \mathrm{~h}$ induction phase preceded by a $69 \mathrm{~h}$ growth phase.

While cultivation parameters may be modified to optimise recombinant protein production [39], the level of initial expression would appear to be mediated by cell density prior to induction. The use of an inducible promoter, such as AOX1 in P. pastoris, allows for the separation of the growth phase from the induction phase [40]. The general trend regarding recombinant expression by Pichia would appear to suggest that the highest titres of recombinant xylanase were attained following the induction of high cell density cultures [41]. Published literature, pertaining to high xylanase expression by Pichia, indicated that viable cell density did not increase by any considerable level during the induction period, suggesting that expression was directly influenced by the initial cell density $[38,39,41,42]$.

The molecular mass of the wild type xylanase from $T$. lanuginosus 195 was estimated to be $22 \mathrm{kDa}$ by SDS-PAGE (Fig. 1). The banding pattern generated by the recombinant xylanase in Fig. 6a may have been, in part, mediated by inefficient signal sequence cleavage at the N-terminus [37]. Proline residues have been reported to influence the efficacy of both Kex2 and Ste13 proteases, responsible for cleaving the $\alpha$-factor signal upstream of the heterologous gene in the pPic9K vector [14]. Sequencing carried out in the present study identified a codon encoding proline near the $5^{\prime}$ end of the xylanase gene (data not shown). Furthermore, the xylanase gene did not appear to encode the tripeptide sequences commonly associated with N-linked glycosylation (Asp-X-Ser or Asp-X-Trp) [43], but increased mass of the recombinant xylanase may have been influenced by O-linked glycosylation or mannosylation [44].

Enhanced recombinant xylanase production may be achieved following manipulation of codon hierarchy within the heterologous gene [45]. The efficacy of the signal sequence peptide has also been documented to influence heterologous expression [46]. It is anticipated that the eventual elucidation of such potential limiting factors, as well as optimisation of fermentation parameters, may serve to enhance the typically low titres synonymous with heterologous protein expression.

\section{Acknowledgement}

The support, both financially and professionally, offered by Alltech is greatly appreciated. 


\section{References}

[1] Pérez J, Munoz-Dorado J, De La Rubia T, Martinez J. Biodegradation and biological treatments of cellulose, hemicellulose and lignin: an overview. Int Microbiol 2002;5:53-63.

[2] Juhász T, Szengyel Z, Réczey K, Siika-Aho M, Viikari L. Characterisation of cellulases and hemicellulases produced by Trichoderma reesei on various carbon sources. Process Biochem 2005;40:3519-25.

[3] Tuomela M, Vikman M, Hatakka A, Itavaara M. Biodegradation of lignin in a compost environment: a review. Bioresour Technol 2000;72:169-83.

[4] Thomson JA. Molecular biology of xylan degradation. FEMS Microbiol Lett 1993;104:65-82.

[5] Polizeli MLTM, Rizzatti ACS, Monti R, Terenzi HF, Jorge JA, Amorim DS Xylanases from fungi: properties and industrial applications. Appl Microbiol Biotechnol 2005;67:577-91.

[6] Tengerdy RP, Szakacs G. Bioconversion of lignocellulose in solid substrate fermentation. Biochem Eng J 2003;13:169-79.

[7] Sun Y, Cheng J. Hydrolysis of lignocellulosic materials for ethanol production: a review. Bioresour Technol 2002;83:1-11.

[8] Singh S, Madlala AM, Prior BA. Thermomyces lanuginosus: properties of strains and their hemicellulases. FEMS Microbiol Rev 2003;27:3-16.

[9] Damaso MCT, Andrade CMMC, Pereira NJ. Use of corncob for endoxylanase production by thermophilic fungus Thermomyces lanuginosus IOC-4145. Appl Biochem Biotechnol 2000;84-86:821-34.

[10] Jiang Z, Yang S, Yan Q Li L, Tan S. Optimising xylanase production by a newly isolated strain CAU44 of the thermophile Thermomyces lanuginosus. World J Microbiol Biotechnol 2005;21:863-7.

[11] Singh S, Pillay B, Dilsook V, Prior BA. Production and properties of hemicellulases by a Thermomyces lanuginosus strain. J Appl Microbiol 2000;88:975-82.

[12] Sun JY, Liu MQ, Weng XY, Qian LC, Gu SH. Expression of recombinant Thermomonospora fusca xylanase A in Pichia pastoris and xylooligosaccharides released from xylans by it. Food Chem 2007;104:1055-64.

[13] Hough DW, Danson MJ. Extremozymes. Curr Opin Chem Biol 1999;3:39-46.

[14] Cereghino JL, Cregg JM. Heterologous protein expression in the methylotrophic yeast Pichia pastoris. FEMS Microbiol Rev 2000;24:45-66.

[15] Cregg JM, Barringer KJ, Hessler AY, Madden KR. Pichia pastoris as a host system for transformations. Mol Cell Biol 1985;5:3376-85.

[16] Pemberton PA, Bird PI. Production of serpins using yeast expression systems. Methods 2004;32:185-90.

[17] Mattanovich D, Gasser B, Hohenblum H, Sauer M. Stress in recombinant protein producing yeasts. J Biotechnol 2004;113:121-35.

[18] Bailey MJ, Poutanen K. Production of xylanases by strains of Aspergillus. Appl Microbiol Biotechnol 1989;30:5-10.

[19] Bradford MM. A rapid and sensitive method for the quantitation of microgram quantities of protein utilising the principle of protein-dye binding. Anal Biochem 1976;72:248-54.

[20] Laemmli UK. Cleavage of structural proteins during the assembly of the head of bacteriophage T4. Nature 1970;227:680-5.

[21] Ryan SE, Nolan K, Thompson R, Gubitz GM, Savage AV, Tuohy MG. Purification and characterisation of a new low molecular weight endoxylanase from Penicillium capsulatum. Enzyme Microbiol Technol 2003;33:775-85.

[22] Sambrook J, Fritsch EF, Maniatis T. Molecular cloning: a laboratory manual. 2nd ed. Cold Spring Harbor, New York: Cold Spring Harbor Laboratory Press; 1989.

[23] Cregg JM, Russell KA. Transformation. In: Higgins DR, Cregg JM, editors. Methods in molecular biology. New Jersey: Humana Press; 1998. p. 27-39.

[24] Chen C-C, Wu P-H, Huang C-T, Cheng K-J. A Pichia pastoris fermentation strategy for enhancing the heterologous expression of an Escherichia coli phytase. Enzyme Microbiol Technol 2004;35:315-20.

[25] Carberry S, Neville CM, Kavanagh KA, Doyle S. Analysis of major intracellular proteins of Aspergillus fumigatus by MALDI mass spectrometry: Identification and characterisation of an elongation factor $1 \mathrm{~B}$ protein with glutathione transferase activity. Biochem Biophys Res Commun 2006;341:1096-104.

[26] Singh S, Pillay B, Prior BA. Thermal stability of $\beta$-xylanases produced by different Thermomyces lanuginosus strains. Enzyme Microbiol Technol 2000;26:502-8.
[27] Schlacher A, Holzmann K, Hayn M, Steiner W, Schwab H. Cloning and characterisation of the gene for the thermostable xylanase XynA from Thermomyces lanuginosus. J Biotechnol 1996;49:211-8.

[28] Raedschelders G, Fierens K, Sansen S, Rombouts S, Gebruers K, Robben J, et al. Molecular identification of wheat endoxylanase inhibitor TAXI-II and the determinants of its inhibition specificity. Biochem Biophys Res Commun $2005 \cdot 335: 512-22$

[29] Goesaert H, Elliott G, Kroon PA, Gebruers K, Courtin CM, Robben J, et al. Occurrence of proteinaceous endoxylanase inhibitors in cereals. Biochim Biophys Acta, Proteins Proteomics 2004;1696:193-202.

[30] Deng P, Li D, Cao Y, Lu W, Wang C. Cloning of a gene encoding an acidophilic endo- $\beta-1,4$-xylanase obtained from Aspergillus niger CGMCC1067 and constitutive expression in Pichia pastoris. Enzyme Microbiol Techno 2006;39:1096-102.

[31] Cesar T, Mrsa V. Purification and properties of the xylanase produced by Thermomyces lanuginosus. Enzyme Microbiol Technol 1996;19:289-96.

[32] Mazeau K, Moine C, Krausz P, Gloaguen V. Conformational analysis of xylan chains. Carbohydr Res 2005;340:2752-60.

[33] Puls J, Schuseil J. Chemistry of hemicelluloses: relationship between hemicellulose structure and enzymes required for hydrolysis. In: Coughlan MP Hazelwood GP, editors. Hemicellulose and hemicellulases. London: Portland Press; 1993. p. 1-28.

[34] Li K, Azadi P, Collins R, Tolan J, Kim JS, Eriksson KEL. Relationships between activities of xylanases and xylan structures. Enzyme Microbiol Techno 2000;27:89-94.

[35] Damaso MCT, Andrade CMMC, Pereira Jr N. Production and properties of the cellulase-free xylanase from Thermomyces lanuginosus IOC-4145. Braz J Microbiol 2002;33:333-8.

[36] Wakiyama M, Tanaka H, Yoshihara K, Hayashi S, Ohta K. Purification and properties of family-10 endo-1,4-b-xylanase from Penicillium citrinum and structural organisation of encoding gene. J Biosci Bioeng 2008;105 367-74.

[37] Damaso MCT, Almeida MS, Kurtenbach E, Martins OB, Pereira NJ, Andrade CMMC, et al. Optimised expression of a thermostable xylanase from Thermomyces lanuginosus in Pichia pastoris. Appl Environ Microbiol 2003;69: 6064-72.

[38] Ruanglek V, Sriprang R, Ratanaphan N, Tirawongsaroj P, Chantasigh D, Tanapongpipat $S$, et al. Cloning, expression, characterisation, and high celldensity production of recombinant endo-1,4- $\beta$-xylanase from Aspergillus niger in Pichia pastoris. Enzyme Microbiol Technol 2007;41:19-25.

[39] Zhou C, Li D, Wu M, Wang W. Optimised expression of an acid xylanase from Aspergillus usamii in Pichia pastoris and its biochemical characterisation. World J Microbiol Biotechnol 2008;24:1393-401.

[40] Görgens JF, Passoth V, van Zyl WH, Knoetze JH, Hahn-Hagerdal B. Amino acid supplementation, controlled oxygen limitation and sequential double induction improves heterologous xylanase production by Pichia stipitis. FEMS Yeast Res 2005;5:677-83

[41] Tsai CT, Huang CT. Overexpression of the Neocallimastix frontalis xylanase gene in the methylotrophic yeasts Pichia pastoris and Pichia methanolica. Enzyme Microbiol Technol 2008;42:459-65.

[42] Cheng YF, Yang CH, Liu WH. Cloning and expression of Thermobifida xylanase gene in the methylotrophic yeast Pichia pastoris. Enzyme Microbiol Technol 2005;37:541-6.

[43] Conesa A, Punt PJ, van Luijk N, van den Hondel CAMJJ. The secretion pathway in filamentous fungi: a biotechnological view. Fungal Genet Biol 2001;33 155-71.

[44] Xie YF, Chen H, Huang BR. Expression, purification and characterisation of human IFN- $\lambda 1$ in Pichia pastoris. J Biotechnol 2007;129:472-80.

[45] Yin E, Le Y, Pei J, Shao W, Yang Q. High-level expression of the xylanase from Thermomyces lanuginosus in Escherichia coli. World J Microbiol Biotechnol 2008;24:275-80.

[46] Ghosalkar A, Sahai V, Srivastava A. Secretory expression of interferon-alpha $2 b$ in recombinant Pichia pastoris using three different secretion signals. Protein Expr Purif 2008;60:103-9. 